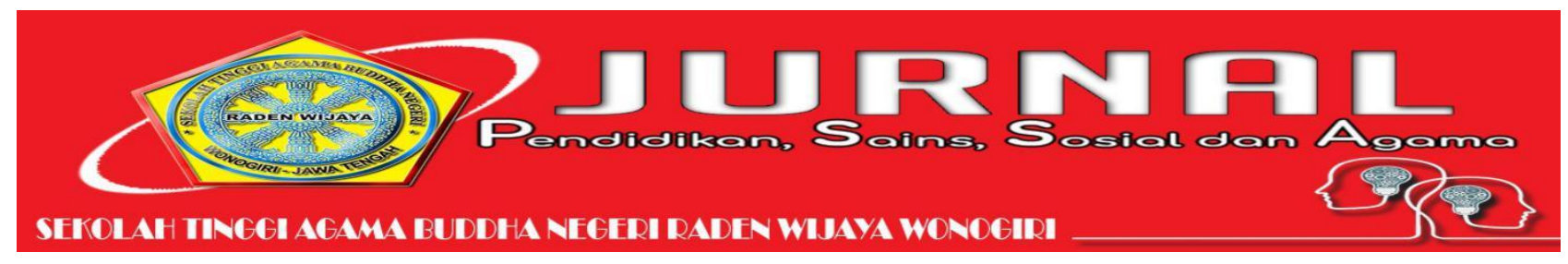

\title{
NILAI NASIONALISME DALAM PERINGATAN PERAYAAN HARI BESAR KEAGAMAAN SECARA BERSAMA PADA WARGA DESA SAMPETAN BOYOLALI UNTUK MENUMBUHKAN SADDHA
}

\author{
Ari Mariyono \\ STABN Raden Wijaya Wonogiri Jawa Tengah \\ Arimariyono16@gmail.com
}

\begin{abstract}
Abstrak
Tujuan Penelitian dalam penelitian ini adalah Mendeskripsikan pelaksanaan Pelaksanaan Peringatan Perayaan Hari Besar Keagamaan secara Bersama pada Warga Desa Sampetan Boyolali, serta Mendeskripsikan nilai Buddhis terkaid Nasionalisme pada Pelaksanaan Peringatan Perayaan Hari Besar Keagamaan secara Bersama pada Warga Desa Sampetan Boyolali. Penelitian ini merupakan penelitian deskriptif dengan mengunakan pendekatan Kualitatif melalui Study Kasus.

Hasil penelitian menunjukan bahwa: (1) Kebersamaan Perayaan hari Besar Keagamaan tersebut mampu menjaga nilai nasionalisme pada warga : (2) Kebersamaan Perayaan hari Besar Keagamaan tersebut mampu memberikan pendidikan pendewasaan Keberagaman : (3) . Nilai Nasionalisme dalam Kebersamaan Warga Desa Sampetan untuk Menumbuhkan Keyakinan (saddha) pada perayaan Hari Besar keagamaan dalam Buddhism sebagai wujud pengembangan penerapan sifat Luhur ( Brahma Vihara) serta sepuluh kriteria seorang pemimpin yang baik dalam Buddhism (Dasa Raja Dhamma).
\end{abstract}

Kata Kunci: Nasionalisme, Menumbuhkan Keyakinan (saddha) pada perayaan Hari Besar keagamaan

\section{Abstract}

The purpose of this research is to describe the implementation of the Commemoration of the Celebration of Religious Holidays Together in the Villagers of Sampetan Boyolali As well as describing the value of Buddhism based on Nationalism in the Commemoration of the Celebration of Religious Holidays Together in Sampetan Boyolali Villagers. This research is a descriptive study using a qualitative approach through case studies.

The results showed that: (1) The Togetherness of the Celebration of Religious Holidays was able to maintain the value of nationalism in the citizens: (2) The Togetherness of the Celebration of Religious Holidays was able to provide maturity diversity education: (3). The Value of Nationalism in the Togetherness of Sampetan Villagers to Foster Confidence (saddha) in the celebration of religious holidays in Buddhism as a form of developing the application of the quality of the Noble (Brahma Vihara) as well as the ten criteria for a good leader in Buddhism (Dasa Raja Dhamma)

Key Word: Nationalism, Growing Confidence (saddha) on the celebration of religious holidays 


\section{PENDAHULUAN}

Nasionalisme merupakan tanggung jawab dari semua warga negara. Dalam Negara Kesatuan Republik Indonesia ini, nasionalisme harus tetap dipertahankan dari generasi ke generasi. Dengan melihat perjuangan para pahlawan dahulu pada zaman penjajahan, betapa sulitnya untuk mewujudkan Negara Kesatuan Republik Indonesia yang merdeka ini, yang terdiri dari keanekaragaman suku, budaya, adat istiadat, agama, ras dan kemajemukan lainnya. Untuk mewujudkan negara yang merdeka dibutuhkan rasa persatuan dan kesatuan yang tinggi serta komitmen dalam berjuang bersama serta rasa syukur atas kekayaan dari berbagai kemajemukan yang ada di Indonesia. Hal inilah konon yang menjadikan tonggak sejarah dan senjata yang ampuh untuk mengusir penjajah.

Melalui perjuangan pergerakan nasional pada zaman penjajahan itu seperti lahirnya Sumpah pemuda, Gerakan Budi Utomo, serta gerakan perjuangan nasional lainnya, sehingga saat ini warga negara Indonesia dapat menikmati kemerdekaan sebagai hasil dari perjuangan para tokoh nasionalisme terdahulu. Oleh sebab itu nasionalisme mempunyai banyak fungsi, salah satunya wujud adalah nasionalisme yang mampu membawa suatu bangsa pada kehormatan dan jati dirinya. Hal itu akan terwujud jika setiap warga sadar dan memiliki jiwa patriotisme yang tinggi.

Kesadaran atau jiwa patriotisme yang tinggi dapat diwujudkan melalui kesadaran mencintai bangsa dan negaranya, dengan ikhlas akan memberikan pengorbanan dan dharma bhakti kepada bangsa dan negara (I Gusti Ngurah Oka Diputhera, 1987: 71). Selain itu pencerminan jiwa nasionalisme terlihat dari sikap setiap warga negara yaitu dengan menunjukkan rasa tanggung jawab dalam segala tindakan serta mengutamakan kepentingan bersama. Dalam kondisi suatu bangsa yang telah merdeka ini ciri pencerminan jiwa nasionalisme dapat dilakukan melalui berbagai tindakan, sebagai contoh: mencintai produk dalam negeri, menyumbangkan kemampuannya untuk bangsa dan negara melalui tindakan yang profesional dalam bidang yang ditekuni, peduli serta memiliki jiwa sosial yaitu suka menolong terhap penderitaan orang lain. Pada masa kemerdekaan ini diharapkan setiap warga negara mampu berperan serta mengisi hasil perjuangan dengan menyumbangkan semua potensi dan keterampilan yang dimiliki untuk kemajuan bersama. Namun demikian, pada kenyataannya masih banyak tindakan yang sangat bertentangan dari nasionalisme itu sendiri. Dalam menjaga keutuhan nasional dibutuhkan individu yang memiliki jiwa nasionalisme yang tinggi. Akan tetapi nasionalisme di Indonesia saat ini semakin menurun, seperti banyaknya tindakan dari individu yang semakin egois, baik di kalangan pemerintah maupun masyarakat.

Sebagai contoh, adaya perang antar suku, agama, pemberontakan untuk memisahkan diri dari Negara kesatuan Republik Indonesia, dan tindakan lainnya. Peristiwa Kasus berbau agama berupa Gesekan umat MTA dan NU di Boyolali, Demak, Blora Sragen yang sempat membuat perhatian sampai menjadi sorotan Kapolda Jawa Tengah ( Kirono, 2017 : 76). Konflik tersebut bersumber dari ketidak Dewasaan cara pandang Beragama dalam keberagaman oleh para pimpinan masyarakat, tokoh masyarakaat dan tokoh agama. Kasus lain Penistaan Agama di DKI Jakarta akan tetapi menjadi masalah nasional menjelang akhir tahun 2016 tepatnya menjelang Pilkada. Kasus tersebut berujung pada 9 mei 2017 dengan ketetapan Majelis hakim di Pengadilan Negeri Jakarta menjatuhkan hukuman dua tahun pidana penjara kepada Gubernur DKI Jakarta, Basuki Tjahaya Purnama (Ahok).

Nasionalisme mempunyai peran yang sangat penting dalam menentukan kemajuan serta kesejahteraan bangsa. Nasionalisme ini merupakan kesadaran yang harus dimilikki oleh setiapwarga negara. Nasionalisme muncul karena memiliki rasa kesatuan serta tanggung jawab untuk menjalani kehidupan bersama dalam mewujudkan luhur perjuangan para pendiri bangsa. Dalam kesejahteraan suatu bangsa, nasionalisme dan nilai-nilai keagamaan harusnya mempunyai keseimbangan yang baik untuk kemajemukan 
bangsanya. Akan tetapi fakta saat ini sangatlah berkebalikan, nasionalisme menurun karena doktrin dari ajaran keagamaan, serta paham sejenisnya yang disebabkan oleh kepentingan golongan tertentu. Kondisi seperti itu menunjukkan bahwa sebagai warga negara, orang tersebut telah melupakan kemerdekaan yang dicapai, dan keengganannya untuk melanjutkan perjuangan dalam mengisi kemerdekaan.

Dengan melihat kemajemukan yang ada dalam negara kesatuan Republik Indonesia ini, nasionalisme mempunyai peran yang sangat penting terutama dalam mewujudkan pertahanan serta keamanan stabilitas nasional. Seperti kita ketahui, belakangan ini banyak terjadi konflik sosial, serta upaya pemberontakan di berbagai daerah untuk lepas dari negara kesatuan ini. Selain itu dalam lingkup pemerintahan sikap nasionalisme semakin memudar, yang ditandai oleh banyaknya tindakan korupsi, kolusi, nepotisme, dan penggusuran tanah, serta kebijakan-kebijakan yang merugikan salah-satu pihak. Kondisi seperti itu perlu diperbaiki bersama dalam rangka mengisi kemerdekaan, sehingga semua generasi muda bangsa diharapkan mampu memberikan sumbangan dan mengoptimalkan potensi dirinya untuk kemajuan bangsa dan negara. Dengan demikian jiwa patriotisme akan tumbuh di dalam diri generasi muda sebagai wujud dari nasionalisme.

Untuk membangun nasionalisne sangat diperlukan kesadaran berbangsa, bernegara, dan beragama, agar tercipta kelestarian kerukunan hidup. Dengan adanya kelestarian dan kerukunan hidup maka rasa cinta tanah air dapat terwujud. Nasionalisme ini sangat berarti bagi setiap warga negara dalam menjaga keutuhan kesatuan bangsanya. Paham untuk mencintai bangsa dan negara menurut nilai-nilai Buddhisme ditekankan pada sumber daya manusia yang memiliki kepekaan untuk peduli dengan sesama dan sebagai ciri khas Buddhisme menghendaki kebahagiaan dan kesejahteraan semua makhluk, di mana setiap warga dapat berperan dalam kedudukan bermasyarakat. Sebagai contoh jiwa seorang pemimpin harus bersedia mengabdikan dirinya untuk kepentingan rakyat, seperti yang terdapat dalam Nandiamigga Jataka (Cowell, 2005: 174) menyebutkan sepuluh kriteria seorang pemimpin.

Agama mempunyai peran yang nyata, karena mempunyai potensi yang ideal dalam menumbuhkan nasionalisme untuk mengisi kemerdekaan ini. Permasalahan agama merupakan bagian yang teramat peka dalam kehidupan manusia, ketersingungan terhadap sensivisitas keagamaan akan mengusik terjadinya ketidak harmonisan, untuk itu para pemuka agama dan para ahli perbandingan agama mengemukakan gagasan untuk nemumbuhkan toleransi dengan gagasan sinkretisme, rekonsepsi, sintesis, pengantian, agree in disagreement (Faisal 11: 2012). Melalui gagasan tersebut diatas diharapkan memberikan konsribusi dalam menumbuhkan nasionalisme untuk merawat toleransi dalam kehidupan sosial. Peran ini dapat terlihat dalam bergagai hal yaitu wujud keyakian teologis atau simbulisme ritual, selain itu dapat terwujud dalam kegiatan yang nyata baik langsung ataupun tidak langsung yang berdampak pada kehidupan sosial (Faisal, 111: 2012).

Untuk menemukan solusi terhadap permasalahan ini terkaid keyakinan teologis atau simbul ritual, wujud yang nyata dalam kegiatan maka penulis tertarik dan terdorong untuk bersusaha memberikan deskripsi mengenai " Nilai Nasionalisme dalam Peringatan Perayaan Hari Besar Keagamaan secara Bersama pada Warga Desa Sampetan Boyolali untuk menumbuhkan Saddha"

Kehidupan berbangsa dan bernegara membutuhkan suatu perjuangan untuk mencapai cita-cita bersama. Perjuangan tersebut mengacu pada tujuan pembentukan sebagai negara yang berdaulat. Dalam negara kesatuan Republik Indonesia ini mempunyai empat tujuan nasional yaitu: melindungi segenap bangsa Indonesia dan seluruh wilayah tanah air, mensejahterakan kehidupan rakyat, mencerdaskan kehidupan bangsa, dan ikut serta membangun kehidupan dunia yang damai dan merdeka (Gea, 2003: 69). Upaya mewujudkan tujuan nasional dibutuhkan kesadaran berbangsa dan bernegara dari setiap 
warga negara. Kesadaran berbangsa dan bernegara ini mencerminkan nasionalisme.

Nasionalisme menurut Mulkhan

(1996: 14) adalah sebuah gagasan mengenai kesatuan kebangsaan dalam suatu wilayah politik kenegaraan. Kesatuan kebangsaan dalam hal ini merupakan kesatuan dari berbagai perbedaan yang ada dalam wilayah tersebut yang memiliki kesamaan berpikir dalam mewujudkan cita-cita bersama. Pendapat tersebut sejalan dengan Hans Kohn (Juergensmeyer, 1998: 24) yaitu mendefinisikan nasionalisme sebagai suatu kelompok manusia yang menerima sikap politik yang sama dan masing-masing individu dari sekelompok manusiatersebut memaksimalkan segala kemampuannya untuk kepentingan bangsa dan negaranya. Kedua pendapat tersebut memiliki kesamaan yaitu peran warga negara yang memiliki rasa patriotisme untuk mencapai kemajuan bersama.

Pengertian nasionalisme dalam pidato Soekarno tanggal 1 Juni 1945 yaitu menyatakan bahwa nasionalisme adalah cinta sepenuh hati kepada bangsanya, rasa bangga bahwa kita orang yang memiliki satu kebangsaan yaitu adanya satu rasa persatuan di antara orang-orang yang berbeda, yang memiliki kesamaan sejarah penderitaan karena penjajahan dan perjuangan mencapai kemerdekaan (Suseno, 2006: 185). Nasionalisme dapat disebut sebagai semangat kebangsaan atau cinta terhadap tanah air yang muncul karena rasa kebersamaan, perasaan senasib sepenanggungan dari semua golongan dan untuk mencapai satu tujuan yaitu bebas dari penjajahan. Dengan terbebasnya dari penjajahan maka membuka kesempatan warga negara untuk menentukan arah kemajuan bangsa dan mengisi kemerdekaannya.

Nasionalisme mempunyai peran yang sangat penting dalam kemajuan serta kesejahteraan bangsa. Dapat dikatakan nasionalisme muncul karena memiliki rasa kesatuan serta tanggung jawab untuk menjalani kehidupan bersama dalam mewujudkan cita-citanya. Selain itu nasionalisme dapat dikatakan sebagai sarana untuk mengungkapkan jati diri kebangsaan yang berfungsi dalam penetapan identitas
(Heryanto, 1996: ix). Selain itu nasionalisme secara umum diartikan sebagai ajaran atau paham untuk mencintai bangsa dan negara sendiri.

Dari beberapa pendapat tersebut di atas, dapat diambil kesimpulan bahwa nasionalisme merupakan wujud cinta terhadap tanah airnya atau patriotisme yang timbul karena adanya persamaan nasib dan sejarah serta kepentingan untuk hidup bersama sebagai suatu bangsa yang merdeka, bersatu, berdaulat, dan maju dalam satu kesatuan bangsa, negara dan cita-cita bersama guna mencapai dan memelihara serta menjadikan identitas persatuan, kemakmuran dan kekuatan atau kekuasaan negara kebangsaan yang bersangkutan.

Peringatan Perayaan Hari Besar Keagamaan dapat dimaknai bahwa merupakan nilai sejarah perkembangan dalam perjalanan sebuah kepercayaan atau nilai sejarah dalam kaitanya terhadap kitab suci atau guru junjungan dalam tiap kepercayaan. Dalam hal ini sebagai salah satu contoh hari besar dalam agama Buddha yaitu Waisak. Waisak ini memiliki makna penting didalamnya dan tentunya semua hari besar keagamaan lainya terdapat makna penting dari masing-masing sesuai dalam kisah perkembangan agamanya. Secara umum hari besar keagamaan memiliki makna latar belakang dan historis yang dialami oleh Guru junjungannya. Contoh Waisak ini merupakan hari besar yang berlatar belakang historis mengyangkut kehidupan Buddha Gautama. Hari Besar ini diberi nama yang sama dengan nama bulan yang bersangkutan dan selalu bertepatan dengan saat bulan purnama, namun penentu hari dan tanggalnya pada berbagai Negara bisa bergam karena pengaturan system penangalan yang berbeda, misalnya di Indonesia penentuan purnama menurut kalender Imlek, Jawa dan Bali. Oleh karena itu penentuan tepatnya hari-hari suci mempergunakan Almanak Astronomi atau Perhitungan astronomi yang sangat detail sampai pada jam, detiknya saat peringatan hari besar keagamaan khususnya waisak dalam purnama sidi (Mukti 86: 2006)

Saddha dalam pemahaman Buddhism ini dapat diartikan sebagai kepercayaan untuk 
meneladani dan melaksanakan ajaran dari Tri Ratna (Buddha, Dhamma dan Sangha) untuk meningkatkan kwalitas hidup (Majjima Nijaya, III, 4-6). Selain itu Saddha bermakna sebagai keyakinan yang megandung tiga unsur yaitu: keyakinan yang kuat akan sesuatau hal, kegembiraan yang mendalam terhadp sifat-sifat yang baik, harapan untuk memperoleh sesuatu di kemudian hari. Keyakinan atau saddha ini menekankan aspek melihat, mengetahui, dan memahami (Mukti $30: 2006)$.

\section{METODE}

Penelitian ini mempergunakan paradigma budaya, maka rancangan penelitiannya berkarakteristik kualitatif. Kirk dan Miller (dikutip Moleong, 2013; 4) menyatakan penelitian kualitatif adalah tradisi tertentu dalam ilmu pengetahuan sosial yang secara fundamental tergantung pada pengamatan manusia dalam kawasannya sendiri dan berhubungan dengan orang-orang tersebut dalam bahasanya dan dalam peristilahannya. Lokasi penelitian yang dipilih adalah di Desa Sampetan, Kabupaten Boyolali. Lokasi penelitian dilakukan karena beberapa pertimbangan diantaranya sebagai salah saatu Desa yang majemuk ditinjau dari keanekaragaman agama, kepercayaannya. Selain itu sebagai salah saatu Desa yang memeiliki keunikan tersendiri dalam memperingati Hari Besar Keagamaan dari Masing-masing Agama yang berkembang disana.

Pelaksanaan penilitian ini dilakukan selama kurang lebih enam bulan terhitung mulai sejak Agustus sampai dengan November 2019. Teknik pengumpulan data peneliti menggunakan teknik observasi, wawancara dan dokumentasi.

Teknik analisis data yang digunakan dalam penelitian ini adalah mengacu pada konsep Milles \& Huberman (1992: 15-19) yaitu sebagai berikut:

1. Pengumpulan data yaitu mengumpulkan data di lokasi penelitian dengan melakukan observasi, wawancara, dan dokumentasi dengan menentukan strategi pengumpulan data yang dipandang tepat dan untuk menentukan focus serta pendalaman data pada proses pengumpulan data berikutnya.

2. Reduksi data (Data Reduction) yaitu suatu proses pemilahan, pemusatan perhatian pada penyederhanaan, pengabstrakan dan transformasi data kasar yang ada di lapangan dan diteruskan pada waktu pengumpulan data, dengan demikian reduksi data amulasi sejak peneliti mulai memfokuskan wilayah penelitian.

3. Penyajian data (display data) yaitu rakitan organisasi informasi yang memungkinkan adanya penarikan kesimpulan saat penelitian dilakukan. Dalam penyajian data diperoleh berbagai jenis matrik gambar, jaringan kerja, keterkaitan kegiatan atau tabel.

4. Penarikan kesimpulan (Verifikasi), yaitu dalam pengumpulan data, penelitian harus mengerti dan tanggap terhadap sesuatu yang diteliti langsung di lapangan dengan menyusun polapola pengarahan dan sebab-akibat.

Analisis data penelitian ini menggunakan analisis interaktif. Menurut Miles dan Huberman (1992:20), siklus analisis interaktif dapat digambarkan dalam bentuk skema berikut ini, Penjelasan dari gambar 2 di atas dapat dilihat sebagai berikut :

1. Pengumpulan data, yaitu peneliti mengumpulkan data dengan wawancara dengan Tokoh Agama, unsur Pemerintah Desa, dan perwakilan Masyarakat yang terlibat dalam acara tersebut.

2. Reduksi data, yaitu peneliti memilih dari data-data yang sudah terkumpul untuk di tindak lanjuti baik dari observasi, wawancara maupun dokumentasi Nilai Nasionalisme dalam Peringatan Perayaan Hari Besar Keagamaan secara Bersama pada Warga Desa Sampetan Boyolali untuk menumbuhkan Saddha.

3. Penyajian data, yaitu peneliti menyajikan data yang sudah dikumpulkan dan dipilih untuk kemungkinan ditarik sebuah 
kesimpulan tentang Nilai

Nasionalisme dalam Peringatan

Perayaan Hari Besar Keagamaan secara Bersama pada Warga Desa Sampetan Boyolali untuk menumbuhkan Saddha.

4. Penarikan kesimpulan, yaitu peneliti harus mengetahui latar belakang Nilai Nasionalisme dalam Peringatan Perayaan Hari Besar Keagamaan secara Bersama pada Warga Desa Sampetan Boyolali untuk menumbuhkan Saddha, respon masyarakat, dan pola penanaman kesadaran hidup dalam lingkungan yang plural pada umatnya masingmasing dengan adanya Nilai Nasionalisme dalam Peringatan Perayaan Hari Besar Keagamaan secara Bersama pada Warga Desa Sampetan Boyolali untuk menumbuhkan Saddha" serta dampak positif bagi masyarakat.

\section{HASIL PENELITIAN PEMBAHASAN}

DAN

\section{Pelaksanaan Perayaan Hari-Hari Besar Keagamaan di Desa Sampetan}

Berdasarkan hasil wawancara dengan informan, baik itu tokoh agama, umat/penganut, dan pihak pemerintah tentang Nilai-nilai Nasionalisme dalam Kebersamaan Warga Desa Sampetan untuk Menumbuhkan Keyakinan (saddha) pada perayaan Hari Besar keagamaan kesimpulannya sama. Para tokoh agama dari masing-masing Agama telah menyampaikan tentang keberagaman dan perbedaan di kalangan masyarakat melalui Kegiatan Umat Beragama dan berbagai even keagamaan masing-masing yang dalam pelaksanaannya selalu mengedepankan Gotong Royong dalam masyarakat.

Pada prinsipnya masyarakat yang beraneka ragam agama, suku, adat, dan kebiasaan, serta latar belakang sosial ekonomi tidak ada masalah. Masyarakat mengakui adanya perbedaan dan keragaman dalam tatanan kehidupan. Aktivitas sehari-hari berjalan normal, ketika ada kegiatan kebersamaan masyarakat berbaur bekerja sama tanpa melihat perbedaan.

Berikut hasil wawancara dengan para informan tentang Nilai-nilai Nasionalisme dalam Kebersamaan Warga Desa Sampetan untuk Menumbuhkan Keyakinan (saddha) pada perayaan Hari Besar keagamaan:

Menurut KH. Habib Masturi selalu Ketua Forum Kerukunan Umat Beragama Kabupaten Boyolali menyatakan bahwa Wilayah Sampetan merupakan Wilayah Desa yang Plural yang mana terdapat banyak penganut agama Buddha, Hindu, Kristen, Katolik dan Muslim yang prosentasenya cukup hanya berbeda tipis. Dalam pengamatan kami selaku Lembaga yang dibentuk Oleh Pemerintah terutama sebagai mitra kerja yang difukoskan pada Kerukunan Umat Beragama bahwa Wilayah Sampetan ini masyarakatnya memiliki Toleransi yang tinggi. Hal ini terbukti bahwa Kami selalu terlibat ataupun selalu di berikan Undangan saat Perayaan Hari Besar Keagamaan bahkan Kami diberikan Waktu untuk ikut serta dalam mengisi acara ini jadi kehadiran kami sebagai undangan serta Pengisi acara dalam membina kerukunan beragama. Selain itu kami dalam kepengurusan Kerukunan di Tingkat Kabupaten juga selalu mengkondisikan untuk saling terbuka saling bertukar wawasan dan saling berdiskusi untuk bersama-sama focus pada kerukunan beragama. Pada Kesempatan ini kami juga berencana untuk mengembangkan Desa Sampetan ini sebagai salah satu wakil dari Desa Plural di Wilayah Boyolali yang kami upayakan untuk masuk pada tataran Nasional Sebagai Desa Plural untuk Mewakili JAwa Tenggah pada tahun 2020 nanti ( ini informasi yang kami terima dari Kementrian Agama yang sebagai salah satu mitra kami dalam bertugas). Tidak terlepas dari tema awal bahwa perayaan hari besar keagamaan yang menjadi salah satu tradisi disampetan ini sangatlah perlu dicontoh untuk menjadi sarana pemersatu bangsa. Dengan kegiatan ini mengkondisikan untuk saling mengenal saling memahami satu sama lain. Menurut Beliau, hai tersebut memunculkan paham untuk melihat keyakinan saya benar, keyakinan orang lain juga benar. Meyakini keanekaragaman agama 
dan budaya melalui masing-masing agama. Dan di Islam ditanamkan Islam Nusantara.(wawancara dengan KH. Habib Masturi, tanggal 7 November, di rumah kediamannya.

Dalam penelitian ini, peneliti juga mewawancari Pihak Pemerintah Daerah yang dalam hal ini peneliti melakukan wawancara kepada Kepala Desa Sampetan Bapak Kadar Wardoyo sebagai berikut:

"Dengan tradisi Perayaan Hari Besar Keagamaan yang berjalan di wilayah Kami ini merupakan salah satu tradisi kebudayaan yang perlu dilestarikan dan diwariskan kepada para generasi kami untuk lebih mengedepankan seluruh umat Beragama agar makin sadar pentingnya kedewasaan beragama dan menumbuhkan toleransi. Kegiatan seperti ini merupakan salah satu wujud kekayaan budaya di wilayah kami sekaligus pada kesempatan ini kami memprogramkan untuk pengajuan Desa Wisata. Pengajuan Desa Wisata ini meliputi Wisata Religi yang pada saat ini dibangun Wisma Semedi "Giri Sasono Semedhi oleh Bhikkhu Sangha dan Umat Wilayah Sampetan. Selain itu Wisata Hutan Desa dan Taman Baca sekaligus Bumi Perkemahan " Wisata Gasebo". Selain itu kami mengembangan pengajuan beberapa Lokasi Wisata melalui Progam Alokasi Dana Desa dan berusaha kedepan untuk mengarah apada sponsor untuk peduli terhadap perkembangan wilayah Desa.. (Wawancara dengan Kepala Desa Sampetan Bapak Kadar Wardoyo tanggal 4 Oktober 2019 diKantor Kepala Desa).

Perwakilan dari Tokoh Agama Kristen dalam wawancaranya sebagai berikut:

"Rangkaian acara Perayaan Hari Besar Keagamaan di Sampetan ini telah berjalan lebih dari sepuluhan tahun yang lalu. Kegiatan ini perlu di Uri-uri sebagi media pemersatu warga untuk saling mengenal saling silahturahmi melakukan kunjungan dari rumahkerumah para kluarga yang sedang merayakan hari besarnya. Selain itu kegiatan ini pihak Gereja jikalau merayakan acara Natal juga tidak terlepas kepada seluruh lapisan masyarakat yang terlibat proses perayaan ini. Kegiatan ini berjalan seperti tradisi yaitu menerima kunjungan dari umat lain untuk memberikan ucapan salam kebahagiaan atas perayaan Hari Besar. Selain itu Pihak Gereja juga melibatkan umat lain untuk kegiatan perayaan serta kegitan Bakti Sosial Lainya kegiatan ini merupakan media untuk bersama-masa saling berbuat baik dan salaing mengenal.(wawancara dengan Bapak Pendeta Ratmoko, tokoh agama Kristen tanggal 18 Oktober 2019.

Hasil wawancara dengan tokoh agama Buddha Wakil Ketua Wanita Buddhayana Indonesia DPC Boyolali sebagai berikut:

Pada Dasarnya setiap Agama memiliki hari besar masing-masing. Akan tetapi di Desa Sampetan ini berkembang model perayaan yang berbeda dengan desa sekitarnya. Perayaan Hari besar diSampetan ini selain berjalan di Tempat Ibadah Masing-masing juga terdapat kegiatan lain yatu melalukan Anjangsana atau kunjungan dari Warga Gotong Royong untuk berkunjung pada keluarga atau datang kerumah-rumah para warga yang sedang merayakan hari Besar Keagamaan. Kegiatan ini selih berganti jika saat umat Buddha merayakan Waisak maka Umat Muslim, Krinten, Katolik datang berkunjung kepada pihak umat Buddha yang sedang merayakan hari besarnya, demikian sebaliknya, itulah kondisi yang terjadi pada masyarakat kami di Desa Sampetan. Tentunya kegiatan ini melibatkan Lintas Iman , inilah sebagai wujud Toleransi Umat Beragama yang mana saling mendukung kegiatan masing-masing Agama sebagai cerminan dalam 
menerapkan Tri Kerukunan Beragama (wawancara dengan Ibu Haryati selaku Ketua II Wanita Buddhis Indonesia DPC Boyolali, di kediamannya Ampel, tanggal 17 Oktober 2019).

\section{Nilai Nasionalisme dalam kebersamaan Warga Desa Sampetan Boyolali untuk enumbuhkan Saddha pada Perayaan Hari Besar Keagamaan}

Nasionalisme mempunyai peran yang sangat penting dalam menentukan kemajuan serta kesejahteraan bangsa. Nasionalisme ini merupakan kesadaran yang harus dimilikki oleh setiapwarga negara untuk menumbuhkan kesatuan serta tanggung jawab menjalani kehidupan bersama dalam mewujudkan citacita luhur perjuangan para pendiri bangsa. Dalam kesejahteraan suatu bangsa, nasionalisme dan nilai-nilai keagamaan harusnya mempunyai keseimbangan yang baik untuk kemajemukan bangsanya. Para pemuka agama dan para ahli perbandingan agama mengemukakan gagasan untuk nemumbuhkan toleransi dengan gagasan sinkretisme, rekonsepsi, sintesis, pengantian, agree in disagreement. Melalui gagasan tersebut diatas diharapkan memberikan konsribusi dalam menumbuhkan nasionalisme untuk merawat toleransi dalam kehidupan sosial. Peran ini dapat terlihat dalam bergagai hal yaitu wujud keyakian teologis atau simbulisme ritual, selain itu dapat terwujud dalam kegiatan yang nyata baik langsung ataupun tidak langsung yang berdampak pada kehidupan sosial (Faisal, 111: 2012).

Dalam hal ini salah satu kegitan yang berdampak langsung dalam upaya menjaga Nasionalisme tentunya dapat tercermin melalui kebersamaan Warga Desa Sampetan pada Perayaan Hari Besar Keagamaan yang mana pada dasarnya seluruh warga Negara Indonesia memiliki Kepercayaan dalam Beragama. Melalui rangkaian kegiatan keagamaan dari berbagai kepercayaan yang ada pada masyarakat Desa Sampetan ini tentunya banyak kegiatan yang mendukung Nilai Nasionalime sebagai contoh beberapa Dukuh yang berada di wilayah Sampetan ini yang dalam satu dukuhnya terdapat beraneka Kepercayaan dan selalu merayakan Hari
Besar Keagamaan dengan Nuansa Kebersamaan Warga Gotong Royong yaitu diantaranya Dukuh selorejo, Karangboyo, Purwogondo, Sampetan, Purwosari, Gumuk, Pereng, Pagerjurang, Baturejo, Sukorame, Mungsari. Dari Berbagai dukuh tersebut saat perayaan memiliki karekter yang berbeda akan tetapi sangat mengutamakan makna kebersamaanya.

\section{Pelaksanaan Perayaan Hari Raya di Dukuh Pager Jurang}

Di Dukuh ini sangatlah unik dan menjunjung nilai nilai kebersamaan yang kental melalui berbagai kegiatan diantaranya:

1. Ketika Pengajian atau Acara keagamaan lainya semua warga ikut berpatisipasi baik melalui bantuan iuran bersama sesuai kesepakatan Ketua RT, membantu memberikan konsumsi saat acara serta sumbangan tenaga untuk membantu acara tersebut.

2. Disaat perayaan Hari Besar khususnya warga Dukuh Pagerjurang ini selalu melakukan pesta petasan yang dilakukan secara bersama-sama ( iuran bersama seluruh warga setiap ada Perayaan Hari Besar Warganya baik saat Natal, Waisak Taupun Idul Fitri).

3. Selain Hal diatas sebagai Ciri khusus perayaan hari besar di Desa Sapetan ini yaitu melakukan Kunjungan Anjangsana keliling menuju rumah-rumah warga yang sedang merayakan hari besar untuk ikut serta berbagi kebahagiaan tanpa kecuali baik orang tua , para pemuda dan anakanak.

Pelaksanaan Perayaan Hari Raya di Gotong Rayaong Dukuh Selorejo dan Karangboyo

1. Sebagai Ciri khusus perayaan hari besar di Desa Sampetan ini yaitu melakukan Kunjungan Anjangsana keliling menuju rumah-rumah warga yang sedang merayakan hari besar untuk ikut serta berbagi kebahagiaan tanpa kecuali baik orang tua , para pemuda dan anak-anak.

2. Di Dukuh ini memiliki keunikan jikalau saat perayaan hari besar ada warga yang secar sengaja tidak mengikuti datang 
Anjangsana keliling maka mendapat cemooh oleh warga dan disaat yang bersangkutan merayakan hari besar maka warga akan membalas untuk tidak akan datang pada warga tersebut. Jadi Kebersamaan inilah yang mereka jaga sebagai salah satu wujud kebersamaan dalam kehidupan bermasyarakat.

Kejadian diatas pernah meresahkan warga dan menjadikan perbincangan dan masalah pada dua Gotong royong Selorejo dan Karangboyo. Menurut Pengamatan oleh Bapak Pandeta Ratmoko selaku Petugas Pendeta Gereja di Selorejo dan Karang Boyo menyataan bahwa dalam beberapa tahun terakhir ini telah memulai kembali mendekati pulih seperti dahulu dan hanya ada beberapa Gelintir saja yang belum kembali seperti dulu dan ini menjadi tanggung jawab warga bersama untuk berusaha mengkondisikan agar kembali berjalan seperti dahulu bersatu Guyup Rukun dalam Perbedaan.

Secara Keseluruhan warga Desa Sampetan yang secara rutin merayakan acara Kebersamaan dalam Peringtatan Hari besar ini tidak ada permasalahan, hanya satu titik dukuh di atas yang sempat mengalami sedikit ganguan. Secara Keseluruhan Desa Sampetan konsisi tersebut tidak memberikan banyak pengaruh hanya sebagai hal yang perlu diperhatikan lebih untuk pendekatan secara khusus agar segera pulih serta sedikit ganjalan dalam masyarakat yang sempat kurang baik segera kondusif. Mengingat pentingya nilai persatuan, Toleransi dan Nasionalisme maka Kebersamaan kegiatan Perayaan Hari Besar ini harus tetap menjadikan kesadaran dalam kedewasaan beragama. Selain itu hal yang perlu kita contoh dan tidak kalah penting yaitu semestinya dari lingkungan terkecil inilah hal besar dapat terwujud sebagi contoh: terdapat keluarga yang suami-istri berbeda keyakinan juga saling toleran dan saling bergantian dalam perayaan. Dalam kondisi ini jika dalam anggota keluarga beraneka kepercayaan maka sangat wajar jika setiap hari besar keagamaan selalu melakukan Open House secara bergantian karena anggota keluarga beraneka kepercayaannya dan kegiatan ini tetap selaras berjalan dalam kerukunan.

Nilai Nasionalisme dalam Kebersamaan Warga Desa Sampetan Boyolali untuk ,enumbuhkan Saddha pada Perayaan Hari Besar Keagamaan dapat terwujud melalui pencerminan sifat-sifat luhur Brahma Vihara ; Metta yang artinya cinta kasih yaitu kegiatan ini sebagai media memupuk nilai cinta kasih yang universal kepada sesama yaitu saling berbagi dalam ketulusan melalui saling silahturahmi.

Karuna yaitu kasih sayang yang mana sebagai wujud pengembangan rasa tolerensi sebagai warga masyarakat. Kasih sayang yang tulus terhadap semua makhluk serta memupuk nilai persatuan, Gotong Royong dalam bermasysrakat untuk meningkatkan kepedulian terhadap sesame.

Mudita yaitu memiliki rasa bahagia atas kebahagiaan makhluk lain yaitu melalui ucapan selamat kepada teman, kawan , saudara yang pada saau itu mendapatkan kebahagiaan atau merayakan sesuatu maka sepantasnya kita ikut berbagai.

Upekkha yaitu keseimbangan batin ,yang pada kesempatan ini merupakan wujud ketakwaan dan keimanan pada diri sendiri sebagai makhluk sosial yang memiliki keyakinan terhadap keyakinanya sekaligus menerapkan keyakinanya sebagai bentuk pengamalan dari agamanya dengan sesama harus saling menghormati, menghargai dan mengasihi.

Pengembangan serta aplikasi Empat sifat Luhur ( Brahma vihara) diatas, sebagai salah satu dasar dalam pengembangan Keyakinan atau Saddha. Selain itu kegiatan tersebut secara luas dapat meningkatkan keyakinan (Saddha) melalui pengembangan pelaksanaan pencerminan dari Sepuluh kriteria seorang Pemimpin yang baik (Dasa raja Dhamma) karena pada dasarnya setiap indifidu minimal merupakan pemimpin untuk menata kehidupanya dirinya sendiri Yaitu :

1. Dana atau Menumbuhkan sifat Bermurah Hati melalui wujud Iuran untuk kegiatan Perayaan Secara Bersama dan Bergatian, penyiapan hidangan makanan ringan dan makanan berat untuk menjamu para tamu. 
2. Sila atau Kemoralan yaitu sebagai wujud penerapan Norma tata kehidupan sosial pada masyarakat.

3. Pariccaga atau Rela Berkorban, dalam hal ini tentunya kerelaan untuk meluangkan waktu untuk Opeen House

4. Ajjava atau Kerendahan Hati, ini tercermin pada pelayaan terhadap semua tamu pada saat kunjungan.

5. Maddava atau Ramah Tamah yaitu ramah dan baik dalam menerima kunjungan.

6. Tapa atau Kesederhanaan yaitu tidak berlebihan baik dalam tutur kata ataupun tindakan

7. Khodha atau tidak marah hal ini sangat jelas karena nuansa perayaan sangatlah tepat untuk tidak marah.

8. Avihimsa atau tidak melakukan kekerasan hal ini mencerminkan tuan rumah harus memberikan pelayanan yang terbaik untuk para tamu

9. Khanti atau Kesabaran merupakan salah satu bentuk pelatihan diri untuk selalu mengedepamkan sifat sabar

10. Avirodhana atau tidak bertentangan dengan kebenaran, selalu mengutamakan kebajikan dan tepatlah momen tersebut untuk melakukan kebajikan dan tidak menyimpang dari norma masyarakat.

Salah satu dampak positif yang terkondisi melalui kegiatan ini yaitu Kerukunan hidup beragama. Kerukunan ini sebagai suatu kondisi dimana semua golongan agama bisa bersama-sama secara damai tanpa mengurangi hak dan kebebasan masing-masing untuk menganut dan melaksanakan kewajiban agamanya. Kerukunan yang dimaksud bukan berarti penganut agama yang satu tidak merasa perlu atau menahan diri untuk melibatkan persoalan keberagaman dengan pihak lain, karena kebersamaan menghendaki tenggang rasa, yang hanya benar-benar dimungkinkan jika saling memahami.

Berdasarkan data yang diperoleh melalui wawancara dengan informan bahwa kondisi kerukunan hidup umat beragama di Sampetan Kabupaten Boyolali cukup kondusif. Dari hasil wawancara dengan Tokoh agama selaku Ketua Forum Kerukunan Umat Beragama, dengan perwakilan umat beragama, Pandeta dan dengan perwakilan pemerintah yaitu Kepala Desa Sampetan bahwa kondisi kerukunan antarumat beragama sudah berjalan dengan baik, tidak ada konflik dan cukup kondusif. Kondisi itu bisa terjaga karena saling dewasa dalam beragama dan juga perhatian pemerintah Daerah serta mendapat dukungan dari para penganut agama.

Sejalan dengan hal tersebut di atas, untuk memelihara kerukunan, Buddha memberi petunjuk berupa "Enam faktor yang Membawa Kemajuan" (Saraniya Dhamma), yaitu: (1) cinta kasih diwujudkan dalam perbuatan; (2) cinta kasih diwujudkan dalam tutur kata; (3) cinta kasih diwujudkan dalam pikiran dan pemikiran, dengan memiliki iktikat baik terhadap orang lain; (4)memberi kesempatan kepada sesamanya untuk menikmati apa yang diperoleh secara benar; (5) di depan umum ataupun pribadi ia menjalankan kehidupan bermoral, tidak berbuat sesuatu yang melukai perasaan orang lain; (6) di depan umum ataupun pribadi memiliki pandangan sama, yang bersifat membebaskan dari penderitaan dan membawanya berbuat sesuai dengan pandangan tersebut, hidup harmonis, tidak bertengkar karena perbedaan pandangan $(A$. III, 288-289).

Kondisi kerukunan antarumat beragama terjadi di Sampetan Kabupaten Boyolali sejalan dengan program pemerintah, yakni negara atau pemerintah tidak mencampuri masalah intern agama, baik ajaran maupun kelembagaannya, tetapi pemerintah sangat berkepentingan dengan pembangunan kehidupan beragama, berusaha untuk meningkatkan kesejahteraan rohani rakyatnya dan mengamankan kerukunan antarumat beragama. Dalam hal ini dikembangkan konsep Tri Kerukunan, yaitu kerukunan intern umat beragama, kerukunan antarumat beragama, kerukunan antara umat beragama dan pemerintah.

\section{KESIMPULAN}

Berdasarkan hasil analisis data yang telah dilakukan maka dapat diperoleh kesimpulan sebagai berikut: 
1. Pelaksanaan Peringatan Perayaan Hari Besar Keagamaan secara Bersama pada Warga Desa Sampetan Boyolali telah berjalan lebih dari sepuluhan tahun. Kegiatan ini merupakan sebuah kekayaan tradisi kebudayaan wilayah desa tersebut. Kegiatan ini sebagai sarana untuk meningkatkan rasa kebersamaan, kepedulian dan Toleransi pada kehidupan masyarakat desa Sampetan.

2. Nilai Buddhis terkaid Nasionalisme dalam Kebersamaan Warga Desa Sampetan Boyolali untuk Menumbuhkan Saddha pada Perayaan Hari Besar Keagamaan yaitu mencerminkan pelaksanaan sifatsifat Luhur (Brahma Vihara) sebagai dasar pengembangan saddha atau keyakinan yang secara luas dapat ddiaplikasikan dalam konsep Dasa Raja Dhamma yaitu Kreteria seorang pemimpin yang baik dalam konsep Buddhis. Pada Dasarnya kita manusia merupkan pemimpin yang minimal memimpin dirinya sendiri. Untuk itu segala sesuatu dapat dikembangkan dimulai dari diri sendiri yang mana akan membuat kondisi meningkat pada lingkungan sekitar dan lingkungan yang lebih luas lagi.

\section{Daftar Pustaka}

Arikunto. 2006. Prosedur Penelitian Suatu Pendekatan Prakmatik. Jakarta: Rineka Cipta

Bungin, Burhan. 2008. Analisis Data Penelitian Kualitatif. Jakarta: Raja Grafindo Persada

Departemen Pendidikan Nasional. 2005. Kamus Besar Bahasa Indonesia Pusat Bahasa. Jakarta. PT Gramedia Pustaka Utama

Girimanggala Dkk. 2009. Kotbhah-Kotbhah Panjang Sang Buddha Digha Nikaya. Jakperformancea: Dhamma Citta Press

Hakim, Muhamad Nur. (2003). Islam Tradisionldan reformasiPragmatisme (Agama dalam pemikiran Hasan Hanafi). Malang: Bayu Media Publishng
Haryanto. 2008. Dasar- dasar Penilisan Proposal Penelitian. UGM: Gajah Mada University Press

Herdiansyah , Haris. 2010. Metodelogi Penelitian Kualitatif untuk Ilmu-ilmu Sosial. Jakarta: Salemba Humanika

Kirono, Condro. 2017. Memimpin dalam Kebeagaman, Jawa Tenggah Sprimpim Polda Jawa Tenggah Penerbit Fatawa Publisshing

Milles dan Huberman, A. Michael. 1992. Analisis Data Kwalitatis: Buku Sumber Tentang Metode-metode Baru. Jakarta: UI Press

Moleong, Lexy J. 2013. Metodologi Penelitian Kualitatif. Bandung: PT. Remaja Rosdakarya

Nasikun, dkk. 1996. Nasionalisme. Yogyakarta: Pustaka Pelajar Offset

Pigay, Decki Natalis. 2000. Evolusi Nasionalisme dan Sejarah Konflik Politik di Papua. Jakarta: PT Penebar Swadaya

Piotr Sztomka. (2007). Sosologi Perubahan Sosil. Jakarta: Persada

Pranoto, Suhartono W. 2001. Revolusi Agustus. Yogyakarta: Lapera Pustaka.

Simatupang, dkk. 1987. Peran Agama-Agama dan Kepercayaan terhadap Tuhan Yang Maha Esa dalam Negara Pancasila yang Membangun. Jakarta: PT BPK Gunung Mulia.

Sumartana, Th. 2001. Nasionalisme Etnisitas. Yogyakarta: Pustaka Pelajar.

Suseno, Frans Magnis. 2006. Berebut Jiwa Bangsa. Jakarta: Penerbti Buku Kompas.

Sugiono .2013 . Metode Penelitian Kualitatif, Kualitatif dan Kombinasi ( Meixed Menthods. Bandung: Alfaneta 
Swarnacitta, Kartika dan Upakarika, Ana. 2018. Buku Pendidikan Agama Buddha dan Budi Pekerti. Ehipassiko Fuondation

Vinara. 2008. Ensiklopedia Buddha Dharma. Jakarta: CV. Santusita

Widya, Dharma K. 2005. Kompilasi Istilah Buddhis. Jakarta: Yayasan Dana Pendidikan Buddhis Nalanda.

Wijaya. Edi, Indra Aggara. 2013. Kotbahkotbha menengah Sang Buddha Majimanikaya. Jakperformancea: Dhamma Citta Press 